Portland State University

PDXScholar

Summer 2021

\title{
The Effects of Mental Illness on Capital Sentencing in the State of Oregon
}

Mirtill E. Csikos

Portland State University

Follow this and additional works at: https://pdxscholar.library.pdx.edu/honorstheses

Part of the Criminal Law Commons, Criminal Procedure Commons, and the Psychiatric and Mental Health Commons

Let us know how access to this document benefits you.

\section{Recommended Citation}

Csikos, Mirtill E., "The Effects of Mental Illness on Capital Sentencing in the State of Oregon" (2021). University Honors Theses. Paper 1130.

https://doi.org/10.15760/honors.1161

This Thesis is brought to you for free and open access. It has been accepted for inclusion in University Honors Theses by an authorized administrator of PDXScholar. Please contact us if we can make this document more accessible: pdxscholar@pdx.edu. 
The Effects of Mental Illness on Capital Sentencing in the State of Oregon

\section{by}

Mirtill E Csikos

An undergraduate honors thesis submitted in partial fulfillment of the

requirements for the degree of

Bachelor of Arts

University Honors

and

Psychology

Thesis Advisor

Dr. Marcus Sharpe

Portland State University

202
THE EFFECTS OF MENTAL ILLNESS ON CAPITAL SENTENCING

Abstract

There is emerging awareness on the potential arbitrariness and unconstitutionality of executing persons with mental illness. Most states with current death penalty laws have little to no

protection for severely mentally ill defendants during capital trials. The present paper looked at the effectiveness of sentencing statutes serving the purpose of protecting defendants with severe mental illness in the state of Oregon. Through a careful meta-analysis this research focused on determining how mental illness plays into death penalty decisions and if Oregon's Guilty Except for Insanity defense provides sufficient protection. Furthermore, the question of mental illness as a mitigating factor was explored as well. Attention was given to the current death row population in Oregon which included 24 inmates. Findings of this research concluded that while Oregon's current laws do provide some level of protection the laws are potentially too broad leading to inconsistent applications. The paper provides a discussion on the limitations of these findings and suggested solutions to address the issues highlighted.

Keywords: mental illness, capital punishment, death penalty, Oregon, insanity defense 


\section{The Effects of Mental Illness on Capital Sentencing in the State of Oregon}

Currently, in the United States 27 states, the U.S. government and the U.S. military have capital punishment as a sentencing option (DPIC, 2021a). There are 23 states without the death penalty and three states including Oregon, California, Pennsylvania and the federal government (The United States Department of Justice, 2021) have placed a moratorium on it as of 2011, 2019,2015 and 2021 in order of mention. The only capital crime in the state of Oregon is aggravated murder defined in ORS § 163.095 (DPIC, 2021b; see Appendix A).

Since 2001 the death row population has been declining with currently about 2700 men and women sitting on state or federal death rows or facing the possibility to be resentenced to death (Davis \& Snell, 2018). At the turn of the 21 st century, this number almost reached 3600. The number of executions carried out yearly is outnumbered by how many people are being resentenced to life or less after their sentences are being overturned, have been exonerated, died not from executions, and lastly fewer new capital sentences are made each year. Despite this declining tendency, the death penalty is still a major issue in American society with very divided popular opinions (Smith, 2014). While the supporters of capital punishment are outnumbered in the U.S. population by about 2:1 this public opinion is not reflected in how many states still allow for the death penalty today.

After the death penalty was reinstated in 1976 the Supreme Court has left open the possibility of imposing death on crimes other than murder, like rape or armed robbery (DPIC, 2021c). However, later on, they changed this and the rape of an adult women where no death occurred was deemed unconstitutional to qualify someone for a death sentence. Finally, in the 2008 Kennedy v. Louisiana decision banned capital punishment for any non-homicidal rape. This case resulted in a ban on capital punishment for any crime where there was no death. Therefore, in the modern era all prisoners executed or on death row were convicted of murder. The question of imposing death penalty for treason or espionage is still left open, however.

Despite these most recent developments there are still major problems regarding capital sentencing statutes and execution (DPIC, 2021c). One of these issues is that in many states any participant in a felony can be charged with murder and face the death penalty if a death occurs even if they did not have an active part in it. This is possible under the "law of parties" or "felony murder" laws in some states allowing the execution of someone that did not directly commit the murder. In a minority of cases the person receiving execution have ordered or hired someone to carry out the murder. This does not exclude unarmed accomplices which then begs the question of whether the death penalty is actually reserved for the worst of the worst. Another considerable issue is that many states have capital sentencing statutes that are potentially too broad, embodying almost all cases of murder with little to no attempt at filtering out those most deserving of such a harsh and permanent sentence.

While over the last few decades the size of death row has significantly declined in states and on the federal level as well, time spent on it has grown from years to decades (DPIC, 2021d) This presents different kinds of issues in itself. Major concerns can be raised regarding how this extensive time spent on death row and in solitary confinement affects the inmates' physical and psychological capacities. Many of the incarcerated inmates on death row have mental illnesses and the isolation can further exacerbate their symptoms. Furthermore, older inmates have had or developed over their incarceration physical disabilities presenting the question of whether executing them is not undignified. The length of time spent in solitary confinement in itself can be considered a cruel and unusual punishment bordering torture. On the other hand, speeding up 
the process might not bring the desired solution as this could lead to more innocent people being executed leading to more injustice.

With the amount of time prisoners have to spend on death row awaiting execution or exoneration growing in the last few decades some prisoners have been on death row for over 20 years (DPIC, 2021e). While there they are generally separated from other inmates, they cannot take part in prison educational or employment programs and are extremely restricted in terms of visitation or exercise. A death row inmate spends about 23 hours a day alone in their cell. These circumstances are essentially extended solitary confinement; a punishment used in prisons when inmates misbehave for a very short period of time. However, putting someone through it for decades can lead to severe mental health problems and anxiety. On top of complete isolation these inmates wait for years to find out what will happen to them and when. The uncertainty of when their life will end presents its own issues in itself.

The death row phenomenon is a term used by some psychologists and lawyers to describe what the extended years of isolation and uncertainty can do the death row prisoners and how it can lead to suicide, delusions and insanity (DPIC, 2021e). The psychological effects of this are referred to as the death row syndrome. The concept originates from 1989 the case of Jens Soering. Soering was a German citizen who was charged with murder in Virginia in 1985 and fled to the United Kingdom to avoid execution. To avoid extradition, he argued to the European Court of Human Rights that he would face inhumane conditions while awaiting execution and the wait in itself would be psychologically damaging like torture. In the court's ruling they have cited the death row phenomenon and while he was extradited in 1990 it was with a prosecutorial promise that they would not pursue a capital sentence. Soering's case is heavily cited in extradition cases internationally, however many countries without the death penalty, in general, avoid extradition to the U.S. as the death penalty itself is deemed a violation of human rights.

With all of this in mind the present paper was created to find out how having a preexisting mental health condition, more specifically a severe mental illness would play into receiving a death sentence. The specific question the author was interested in looking at is how having a mental illness at the time of sentencing would play into sentencing decision-making in capital cases. The present paper was written in fulfillment of a bachelor thesis requirement. Therefore, some limitations on the length and specific topic of the paper had to be imposed. To create a manageable research topic the author has limited their focus to the State of Oregon. While Oregon has had a moratorium imposed on its executions for many years now, people can still be sentenced to die, only their execution will not be carried out. So, the goal of this work is to take a look at how mental illness effects capital sentencing in the State of Oregon.

The author's assumption as to what the findings are going to be is that most likely having a severe mental illness will have a negative effect on capital sentencing decisions. To determine the answer to this question the paper first briefly describes the history of death penalty in a bigger context. Then slowly zooming in this is followed by a section on the colorful history of capital sentencing in Oregon. It was also crucial to clearly define what severe mental illness is and then to describe what protections if any exists in law for mentally ill defendants. To come to a conclusion then the author looked at the current death row inmates in Oregon and their specific cases to see if any of them would have qualified for a different sentence under Oregon's laws. This is followed by an analysis on the authors part, coming to a conclusion with the paper closing on a discussion of limitations and suggestions related to the findings.

History of the Death Penalty 
The death penalty has an extensive record throughout history, with death penalty laws dating back to the Eighteenth Century B.C. in the Code of King Hammurabi of Babylon (DPIC, 2021f). It is also present in the Fourteenth Century B.C.'s Hittite Code; in the Seventh Century B.C.'s Draconian Code of Athens, where it served as punishment for all crimes; and in the Fifth Century B.C.'s Roman Law of the Twelve Tablets. During this time, the methods of execution were crucifixion, beating to death, drowning, burning alive, and impalement.

In the Tenth Century, A.D. Britain hanging became the primary method of execution. Under William the Conqueror, no one was allowed to be executed except during wartime (Randa, 1997). However, this did not last long, with Henry VIII executing about 72,000 people in the Sixteenth Century for various crimes. During the following two centuries, crimes punishable by death kept growing in Britain but eventually reached a point where juries recognized its severity. This led to several death penalty reforms, including the number of crimes punishable by death dropping to about half. For apparent reasons, Brittan's death penalty laws had the most considerable influence on executions in America; with the settlers came the death penalty. The first recorded execution in America was Captain George Kendall in the Jamestown colony of Virginia in 1608 for being a spy for Spain. Death penalty laws varied between colonies with no across-the-board standards.

\section{The Idea of Abolishment}

The idea of abolishing the death penalty goes back to the writings of Montesquieu, Voltaire, and Bentham, European theorists, as well as English Quakers John Bellers and John Howard (Schabas, 1997). The most substantial impact on the world's death penalty laws and views was Cesare Beccaria’s 1767 essay, On Crimes and Punishment. In his essay, Beccaria could not find justification for taking one's life, which gave the abolitionists a new voice, with Austria and Tuscany being the first to abolish the death penalty.

Beccaria's essay also affected the U.S. with the first reforms attempted by Thomas Jefferson in Virginia (Bohm, 1999; Randa, 1997; Schabas, 1997). Jefferson's bill proposed that capital punishment should be only for murder or treason and was defeated by only one vote. Dr. Benjamin Rush, one of the signers of the Declaration of Independence and the Pennsylvania Prison Society's founder, challenged the deterrent effect of the death penalty. Rush had the support of Benjamin Franklin and Philadelphia Attorney General William Bradford. His influence on Bradford led to Pennsylvania becoming the first state to consider introducing degrees of murder based on culpability when Bradford became U.S. Attorney General.

Eventually, Pennsylvania revoked the death penalty for all crimes except for first-degree murder in 1794 .

The nineteenth-century brought on a lot of changes across the world. By the end of the century, several countries have completely abolished capital sentencing, while others reformed it (Bohm, 1999). In the U.S., states varied with their treatment of the death penalty. In 1834 , Pennsylvania became the first state to take executions away from the public eye. Michigan became the first state to almost abolish the death penalty altogether in 1986 by only keeping it as punishment for treason. Before the end of the century, Rhode Island and Wisconsin completely abolished it. However, most states have held onto the death penalty and even expanded the list of crimes deserving such a sentence, especially for crimes committed by slaves. Some states started to make reforms to their death penalty statutes in 1838 to make the public more comfortable. These reforms were centered around erasing mandatory death sentencing and introducing discretionary death penalty statutes. By 1963 most mandatory capital sentencing statutes had 
been abolished and a case by case view took over. This was seen as a victory for the abolitionist movement at the time, as before then circumstances were not taken into account at the time of sentencing. By the end of the century, execution methods have changed, with most states switching to the electric chair (Randa, 1997). With the Civil War, attention shifted to the antislavery movement, and the death penalty took the back seat for a bit.

Between 1907 and 1917, six states have abolished the death penalty, and three others limited it two only treason and the murder of law enforcement officers (Bedau, 1998 and Bohm, 1999). However, with the Russian Revolution, people started to worry about a revolution in the U.S. Accompanied by the States entering World War I and the resulting class conflicts, five of the six states have reinstated the death penalty by 1920 . Following this, criminologists were writing papers arguing the importance of capital punishment in society while America struggled with the Prohibition and the Great Depression (Bohm, 1999 and Schabas, 1997). This led to a vast increase in the use of the death penalty from the 1920s till the 1940s, with the most average yearly executions in the State's history during the 1930s. It was not until the 1950s when the American society started to look at capital sentencing differently, partially because the public sentiment has changed with many allied countries abolishing it entirely or limiting it severely.

This shift started with the 1948 Universal Declaration of Human Rights doctrine (Schabas, 1997). In the subsequent years during the 1950s and 1960s, three similar international treaties followed that called for a right to life, with an exception to the death penalty if it was administered with strict procedural safeguards. By the 1980s, a de facto abolition became the trend in Western European countries. In comparison, support for capital punishment has reached an all-time low in the U.S. in 1966 (Bedau, 1997 and Bohm, 1999).

The Constitutionality of Capital Sentencing
Up until the 1960s, the Fifth, Eighth, and Fourteenth Amendments were interpreted to permit capital sentencing (Bohm, 1999). However, that started to be questioned when it was first suggested that the death penalty is "cruel and unusual punishment," therefore unconstitutional under the Eighth Amendment. This shift started with the 1958 Supreme Court case Trop v. Dulles (1958), which resulted in the evolving standards of decency test in law. This test examines the attitude of the American public and prevailing opinions across state legislatures, sentencing juries, judges, scholars, and even considers the international stance. While Trop $v$. Dulles (1958) itself was not a death penalty case, abolitionists argued that it can be applied to capital sentencing and that the American society has matured to the point where its standard of decency should not allow for the death penalty any longer. After this, the Supreme Court started to try to polish up how the death penalty was administered (Bedau, 1997). There were two cases heard in 1968 dealing with the prosecutorial and jury discretion in capital cases. In 1971 they heard another case addressing juror discretion

It was not until the landmark case of Furman v Georgia (1972) that a significant change happened. Here the Court held that the death penalty, at its current state, was violating the Eighth Amendment prohibition on cruel and unusual punishment by providing juries with too much discretion leading to the arbitrary impositions of the death penalty (Furman v. Georgia, 1972). Under this decision, any death penalty statute is unconstitutional if it is too severe for the crime, if it is arbitrary, if it offends the sense of justice by society, or it is not more effective than a less severe sentence. This case's success can be attributed to the fact that it challenged the State of Georgia's capital sentencing statutes under the Eight Amendment's cruel and unusual punishment segment rather than presenting it as a Fourteenth Amendment due process claim (Badeau, 1997). With this decision, the Court voided 40 death penalty statutes across the 
country, reduced 629 death row inmates' sentences, and suspended capital sentencing altogether. However, the case's overall holding was only that currently existing specific death penalty statutes were unconstitutional, not capital sentencing as a concept (DPIC, 2021f).

As a response to the federal moratorium placed on capital punishment, states have passed new legislations tailored to meet the specific requirements laid down by the Supreme Court in Furman v. Georgia (1972). The moratorium was lifted a few years later with the Supreme Court decision of Gregg v. Georgia (1976) allowing states to utilize capital sentencing once again as long as death penalty statutes provided more guidance and less discretion by removing all arbitrary and discriminatory effects (Berkman, 1989). This meant providing sentencing guidelines for the judge and the jury to aid them in deciding whether to impose death, including allowing aggravating and mitigating factors to be introduced to make a sentencing decision. With this decision, the Court also held that the death penalty was constitutional under the Eighth Amendment (DPIC, 2021f)

Gregg v. Georgia (1976) brought three more procedural reforms with the sentencing guidelines, all aimed to establish a degree of consistency in applying the death penalty (Schabas, 1997). The first one is the requirement of bifurcated trials, where the trial is divided up into a separate guilt and sentencing phase. A jury must first determine whether the defendant is guilty, and only if so, can they move on to a second trial solely to select the sentence. The second reform was an automatic appellate review of both the conviction and the sentence. And lastly the third reform was the proportionality principle which holds that the punishment of a crime cannot be "grossly disproportionate" to the defendant's criminal offense by allowing the appellate courts to compare a case in review with other similar cases in the same state. However, these reforms were only guidelines, and states did not have to include all of them in their new and reformed death penalty statutes resulting in today's very colorful capital sentencing palette. Since the reinstatement of capital punishment in 1976, at least 105 of death row inmates, about a 149 people have volunteered for execution (DPIC, 2021f). Volunteers are individuals who terminated further proceedings that would have entitled them for supplementary process before their execution or even terminated their regular appeals.

\section{Limitations on Capital Sentencing}

Even though Europe started to turn away from utilizing the death penalty, the United States has kept it ever since but established some limitations on capital punishment. The first of these limitations came with the Supreme Court case of Coker v. Georgia (1977), where the court held that the death penalty is not adequate punishment for the rape of an adult woman if she is not killed. Later with Ford v. Wainwright (1986), the Court required an adversarial process for determining the competency and banned the execution of insane persons. The question of "mental retardation" - today referred to as "intellectual disability" or "intellectual developmental disorder" - came up first Penry v. Lynaugh (1989), where the court held that the execution of the mentally disabled was constitutional under the Eighth Amendment. It was not until 2002 when in Atkins v. Virginia (2002), the Court finally declared that the national consensus has evolved past it and deemed it unconstitutional in the States. Further limitations came in the late 1980s when the Supreme Court heard three cases regarding the execution of juvenile offenders. Still, it wa not until the case of Roper v. Simmons (2005) that the Court held that a defendant's execution whose crime was committed as a juvenile is unconstitutional.

\section{Death Penalty in Oregon}

The death penalty in Oregon was adopted by statute in 1864 for first-degree murder, however, executions date back about a decade earlier (Terry, 2005). Under the territorial 
government by the Oregon State Supreme Court, the first death sentence carried out can be put to 1951 when William Kendell was hanged in Salem. Prior to that, there are accounts of hangings in 1850 when five Cayuse were hung. Public hangings were carried out until 1903 when the State Legislature amended the law (DPIC, 2021g). Until that date, the authority to carry out executions was secured for the county sheriffs. Since 1903 the state has moved all executions to the Oregon State Penitentiary in Salem in an attempt to restrict public attendance. Between 1903 and 191424 men were hanged at the penitentiary. In 1914 the death penalty was repealed in Oregon via popular vote initiated by Governor Oswald West via a constitutional amendment which became Article 1, 36 of the Oregon Constitution (Horner, 1919). It was reinstated in 1920 by voters repealing Article 1,36, and approving Article 1,37-38 only to be abolished on November 3rd, 1964 with voters passing Measure 1, a constitutional amendment prohibiting capital punishment. Two days after the abolishment in 1964 the Governor at the time, Mark O. Hatfield commuted the death sentences of three death row inmates (DOC, 2021). Between 1920 and 196434 executions were carried out. 16 of those executions were hangings, however, the state introduced a new form of execution to carry out the death penalty in 1931, the usage of lethal gas. 18 people were executed using lethal gas during this period. The last execution took place on August 20, 1962, before the official abolishment in 1964.

\section{8-1996}

In 1978 capital sentencing was reenacted by passing the statute Measure 8 which required the death penalty in certain murder cases, however, the Oregon Supreme Court overturned it in 1981 on the basis that it denied defendants their right to trial by jury as at this time death sentencing was carried out by a trial judge (Ballotpedia, n.d.a). In 1984 voters reinstated the death penalty under Measure 6, creating Article 1, section 40 (OR. Const. art I, $\S 40$ ). Later that year they also passed Measure 7, which required that for an aggravated murder conviction the defendant be given a separate sentencing hearing before the trial jury (Ballotpedia, n.d.b). Aggravated murder as defined by ORS 163.095 and the sentencing options available for the jury can be found under ORS 163.105 (see Appendix B). ORS 163.095 got a huge revision in 2019, severely limiting the type of murders that are eligible for capital punishment (VanderHart, 2019). These options include death, life without the possibility of parole, or "true life" and life imprisonment with a 30-year minimum. To determine the appropriate punishment at the sentencing hearing the jury has to consider three aspects of the aggravated murder: 1 . The murder was deliberate; 2 . Whether a defendant poses a continuing threat to society; and 3. Whether the defendant's acts were unreasonable in response to any provocation by the deceased (DOC, 2021).

\section{After Penry v. Lynaugh (1989)}

In 1989 the United States Supreme Court reversed a Texas death penalty sentence, Penry v. Lynaugh (1989) in violation of the Eighth Amendment. This decision had a huge effect on the Oregon death penalty law as it was based upon Texas law. Before this decision there were three required aspects to be considered when sentencing someone to death (DOC, 2021). Under the Eighth Amendment death penalty should consider the character and record of the individual offender as well as the circumstances of the offense. A fourth question to be considered was added following this decision regarding mitigating evidence:

Should the defendant receive a death sentence, you should answer this question 'no' if you find that there is any aspect of the defendant's character or background or any circumstances of the offense, that you believe would justify a sentence less than death. (DOC, 2021, Resentencing Under Penry section, para. 3). 
Following the Penry decision, 17 Oregon cases were remanded for resentencing, and five of those were resentenced to life with a minimum of 30 years, four got "true life" and eight were resentenced to death. During the 1904-1994 period, 115 people were sentenced to death of which 58 were carried out (DOC, 2021). The rest had their sentences reduced, dismissed, commuted, or have died in prison.

Since 1984

The death penalty in Oregon was last reinstated in 1984, however, the first execution after that did not happen until 34 years later in 1996 and the last execution took place in 1997 (DOC, 2021). On November 22, 2011, Governor John Kitzhaber declared a moratorium on executions (DPIC, 2021g). Both of the last two executions happened during his first administration as governor as the two inmates both dropped their appeal and volunteered for execution. Following Kitzhaber, Governor Kate Brown has extended the state moratorium on executions on February 18,2015 , stating that it requires a broader discussion and until that discussion, she will be upholding the moratorium imposed by her predecessor.

\section{Life on Death Row}

The Oregon State Penitentiary used to house all male offenders convicted of aggravated murder and sentenced to death; female offenders were housed in Coffee Creek Correctional Facility until shortly before their execution (Crombie, 2020a). In Oregon, all death row adults in custody (AICs) were classified as maximum custody level 5 and were single-celled and segregated from the general prison population. In May 2020 the Oregon Department of Corrections announced its plan to dismantle the death row by the summer and send the prisoners living there to the general population and other prison housing. According to this plan, space will be converted into a disciplinary unit for prisoners who commit assaults, engage in extortion,

gang activity, or other illicit conduct behind bars. This plan has been in consideration since 2016 when the agency has first suggested this move in an attempt to lessen psychological harm caused by long-term incarceration practices like segregation (DPIC, 2021h). This follows the national trend with many other states already having made this move. Later in 2020 Oregon followed through this promise and relocated all its death row inmates to the general population (Crombie, 2020b).

\section{Mental IIIness}

In the United States, there is currently no categorical ban on the execution of mentally ill prisoners. While many state legislatures have explored the idea and ideas for bills have floated around, none have been enacted as of yet (Augusta Free Press, 2018; Balmert, 2020; Beitsch, 2017; DeMatteo, 2017). The Supreme Court has acknowledged that mental illness can make a defendant less morally culpable, and it has to be taken into account when making sentencing decisions, but they have not barred the death penalty for individuals suffering from severe mental illness (Task Force on Mental Disability and the Death Penalty, 2005). This was originally the same mentality surrounding intellectual disability and the defendant's young age before the Court has publicly acknowledged that they are factors that result in a diminished capacity to understand the wrongfulness of conduct. According to many mental health experts, specific severe mental health issues like schizophrenia or bipolar disorder can have similar effects, causing cognitive impairments that obstruct decision-making.

\section{Definition of Severe Mental Illness}

The American Psychiatric Association defines mental illness as a health condition that involves significant changes in thinking, emotions, and behavior, causing distress or problems with functioning in social, work, and family activities (APA, 2018). 
Serious mental illness is a mental, behavioral or emotional disorder (excluding developmental and substance use disorders) resulting in serious functional impairment, which substantially interferes with or limits one or more major life activities. Examples of serious mental illness include major depressive disorder, schizophrenia, and bipolar disorder. (Parekh, R., 2018, last section)

According to the American Psychological Association, individuals with severe mental illness face problems on multiple levels of functioning (APA, 2019). On an individual level, they experience difficulties thinking, remembering, problem-solving and social skills that depend on cognitive functioning, such as relating, communicating well and appropriately, and interpreting social cues. Furthermore, they have deficits related to when the illness developed, including the inability to have appropriate relationships, lack of insight and knowledge about the illness. They can be unable to understand how to manage symptoms, and fail to work with mental health professionals to determine primary goals and best treatments. They can experience deficits in basic education and employment skills. On a societal level, they experience difficulties as sometimes they face exclusions from rights and privileges enjoyed by others. There is also stigmatization they have to face making it difficult for them to access health care or other essential services. On a systematic level, there is an organizational inability or unwillingness to provide the most efficient interventions to help these individuals recover and achieve their full functional amplitude.

\section{American Bar Association}

Since 2006 the official stance of the American Bar Association has been that severely mentally ill or disabled defendants should not qualify for the death penalty (Mangels, 2021). This is because according to their statement severe mental disorders significantly impair a defendant's capacity to appreciate the nature, consequences or wrongfulness of their conduct. However, this does not mean they should be absolved of responsibility rather if found guilty they could receive life without parole, they would just not be eligible for capital sentencing.

The ABA have adopted a detailed policy opposing the death penalty for severely mentally ill defendants alongside with the American Psychological Association, American Psychiatric Association and the National Alliance on Mental Illness (Task Force on Mental Disability and the Death Penalty, 2005). While they generally do not speak of supporting or opposing the death penalty as a concept their argument places severe mental illness into the same category as intellectual disabilities and juvenile characteristic of a defendant. According to their statement the death penalty is supposed to serve a retributive and deterrent effect which gets lost if a defendant is unable to appreciate the wrongfulness of their conduct. Their argument also highlights the lack of awareness in our society toward severe mental illness and the scarcity of affordable psychiatric and psychological treatments leaving about 4 million people in the U.S with untreated severe mental illness (Mangels, 2021).

\section{Mental IIIness and the Lav}

The issue of mental illness is far-reaching. In the courtroom, individuals with menta illness are often looked at as aggressive, while society's treatment of mental illness is victimizing people (American Psychiatric Association, 2018). People often look at mental illness as an excuse for getting out of work and to not contribute to society. There is an assumption that people struggling with mental illness are often just blowing it out of proportion, faking it, or looking for sympathy from others. However, severe mental illnesses are pathological medical conditions of the brain (National Institute of Mental Health, 2021). It is not something a person has any control over; they are more like any other disease like heart disease or cancer. Since 
humans are thinking and feeling beings, any sort of disorder in a person's thinking or emotions will affect their ability to function in society. A mental illness is considered severe because of the level of impairment it causes to the individual's daily functioning. Mental illness can flare up at any given time, and it is not unusual that people suffering from it are not able to make rational decisions they need to for their life, like asking for help (National Alliance on Mental Illness, n.d.). Because of the stigmatization in society, it can even be hard to just admit to themselves that they are struggling.

On top of stigmatization other issues surrounding having severe mental illness in the criminal system include having a harder time navigating the system itself (The Tennessee Alliance for the Severe Mental Illness Exclusion [TASMIE], 2019). Individuals struggling with mental illness take longer to process through every stage of the criminal justice process. They are arrested more often than people without mental illness and they serve $30 \%$ longer. This is because of behavioral problems and symptoms resulting in restraint and seclusion which can further induce their symptoms.

According to TASMIE (2019) there are currently four legal mechanisms that address severe mental illness in capital cases: insanity defense, mitigating factors, competency to stand trial, and competency to be executed. None of these legal procedures provide sufficient protection to individuals who have suffered from a severe mental illness at the time of their crime against capital sentencing. The insanity defense is extremely hard to argue as you have to show the defendant did not understand the wrongfulness of their conduct. Using mental illness as a mitigating factor can work, however, a lot of the times the prosecution ends up twisting it and uses symptoms stemming from mental illness as an aggravating factor.

Mental Competency
Many defendants are considered mentally incompetent to stand trial or cannot be executed under not guilty by reason of insanity. Competency to stand trial only means that the defendant must understand the criminal proceedings against them and whether they can assist the defense's preparation (TASMIE, 2019). This is an extremely low bar to meet, and it does not answer whether the individual was impaired at the time of the offense because of a severe mental illness. The question posed here is whether the defendant understands the reason why they are going to be executed. This comes from the Panettiv. Quarterman (2007) ruling, where the Court held that in some cases, defendants can understand the legal processes but are unable to comprehend the reason for the execution itself, in which case they are considered incompetent. The most recent development in this comes from the Madison v. Alabama (2019) decision where the Court ruled that if a prisoner's mental or medical condition prevents them from understanding why they are to be executed, then regardless of what caused the condition they are incompetent.

However, mental incompetency does not expand to severe mental illness (TASMIE, 2019). Most mentally ill defendants cannot qualify for mental incompetency, yet their mental illness has a serious effect on their decision-making, especially if it is undiagnosed or untreated. These defendants are able to understand both the proceedings and the reasons why they are being executed. Yet, at the time of their crime, this does not necessarily translate to full cognitive awareness and control of their decision-making. This effect on decision-making processes is a broad issue in death penalty cases. One out of ten defendants on death row volunteer to be executed by waiving certain trial or appeals rights to foster their execution. Severe mental illness might also result in a diminished capacity to work with trial counsel and can interfere with how 
defendants represent themselves, ultimately affecting the jury's perceptions and decision making when deciding whether the defendant poses a future threat to society.

\section{Not Guilty by Reason of Insanity}

Not guilty by reason of insanity has various names in the United States. Some states refer to it as Guilty but Mentally Ill, Guilty but Insane, or like in the case of Oregon, Guilty Except for Insanity. Legally it is based on the case of Ford v. Wainwright (1986) where the Court held that executing the insane is unconstitutional. However, not guilty by reason of insanity is an extremely high bar to meet as it requires the defense to show that the defendant did not understand the wrongfulness of their conduct (TASMIE, 2019). For this reason, it is rarely used, and even more rarely is it successful. It is raised in about $1 \%$ of cases, and only $25 \%$ of those are successful. So, the not guilty by reason of insanity is not going to keep severely mentally ill individuals from receiving a death sentence.

\section{Mental IIlness as a Mitigating Factor}

Currently, mental illness mostly plays into sentencing proceedings as a mitigating factor during trial procedures brought in by the defense counsel. This is a result of the Furman $v$. Georgia (1972) and Gregg v. Georgia (1976) decisions where the Court required the juries to take into account aggravating and mitigating factors when determining whether life without the possibility of parole (LWOP) or death would be the most appropriate sentence. Statutory aggravating factors are such that an "organized society deems particularly relevant to the sentencing decision," as decided in Gregg v. Georgia (1976). Aggravating factors separate a case where the death penalty is justifiable from a case where capital sentencing is not appropriate. States are mandated by the Court to define aggravating circumstances with sufficient detail to separate defendant's worthy of capital punishment from those that do not fit the requirements
(Zant v. Stephens, 1983). Aggravating factors have to be proven beyond a reasonable doubt by the prosecution, while mitigating circumstances only need to be proven by a preponderance of the evidence (Berkman, 1989).

In Skipper v. South Carolina (1986), the Court defined mitigating circumstances as any evidence "that might serve as a basis for a sentence less than death." The jury must consider all mitigating evidence, not just statutorily defined ones (Lockett v. Ohio, 1978). The purpose of this type of evidence is to provide information such as age, mental capacity, and history of childhood abuse, just to list a few, that would indicate that the defendant is less morally culpable, therefore, should not receive the death penalty. Mental illness as evidence can be introduced as a mitigating factor in capital punishment cases. However, in the penalty phase, jurors and prosecutors are more often turning the mitigating severe mental illness into an aggravating factor (TASMIE, 2019). This is partly because jurors do not necessarily understand or see anything but that the individual is mentally ill and that cannot be changed therefore, they pose a threat to society. So, introducing mental illness at a trial can backfire and result in the jury wanting to execute a person because of their mental illness.

\section{Oregon Death Row}

The American Psychiatric Association, the American Psychological Association, the National Alliance for the Mentally Ill, and the American Bar Association have endorsed resolutions calling for an exemption of the severely mentally ill (Task Force on Mental Disability and the Death Penalty, 2005). 12 states of the 27 that have capital punishment have filed or are currently pursuing a severe mental illness exclusion from the death penalty, however, Oregon is not one of them (TASMIE, 2016). The DPIC website has a collection of proposed bills relating to capital sentencing legislation for 2021 across all states (DPIC, 2021i). Oregon has no 
legislative bills coming up currently that are related to capital sentencing in the state (Oregon State Legislature, 2021). While as stated mental illness can be brought in as a mitigating factor during sentencing decisions Oregon's law detailing mitigating factors does not list mental illness (Oregon Criminal Justice Commission, n.d.). The closest to it is a mitigating departure factor that provides a compelling factor to divert from the Oregon Sentencing Guidelines if the defendant's mental capacity was diminished excluding if that was because of voluntary drug or alcohol consumption (Romano, 2021). However, this is not a sufficient enough limitation when it comes to mental illness as a mitigating factor.

\section{Oregon State Laws}

Currently in the State of Oregon the death penalty is only a sentencing option in aggravated murder cases. Aggravated murder is defined in the ORS 163.095 (see Appendix A) as criminal homicide of two or more persons with three aggravating factors or murder in the second degree with four aggravating factors. The sentencing options for aggravated murder are death, life imprisonment without the possibility of release or parole, or life imprisonment and are defined in ORS 163.105 (see Appendix B). In 2019 Governor Kate Brown has signed Senate Bill 1013 which limited the types of crimes punishable by death (VanderHart, 2019). With this Senate Bill she also removed the future dangerousness factor for juries when they determine sentencing decisions. The Bill also redefined the crime of aggravated murder (S.B. 1013, 2019). Once a defendant was found guilty of aggravated murder there is a separate sentencing hearing where the jury will make a decision of the defendant's sentence in accordance with ORS 163.150 (see Appendix C).

While as stated above there are no laws in Oregon specifically for excluding mentally ill defendants from executions that is because there are some limitations under Oregon's Guilty
Except for Insanity defense. Guilty Except for Insanity is defined in ORS 161.295 (see Appendix D). The qualification for this defense states that as a result of a qualifying mental disorder at the time of the criminal conduct the defendant lacks the capacity to appreciate the criminality of their conduct or are incapable to conform the conduct to the requirements of law. When a defendant is found Guilty Except for Insanity the court has to refer to ORS 161.325 (see Appendix E) in relation to the dispositional order, which requires the court to state the qualifying mental disorder. The definition of what constitutes as a qualifying mental disorder are under ORS 419C.520 (see Appendix F). According to this statute the qualifying serious mental conditions are major depression, bipolar disorder, and psychotic disorders. Abnormalities constituting solely a conduct disorder, or personality disorder or that are manifested only by repeated criminal or otherwise antisocial conduct are not included.

The release authority in Oregon for defendants with psychological or psychiatric problems is the Psychiatric Security Review Board. They are also the entity that defined the terms used in the above-mentioned laws for the Insanity Defense, Qualifying Mental Disorder, and non-Qualifying Mental Disorder (Psychiatric Security Review Board, n.d.). According to their website they have made the definitions in accordance with the American Psychological Association's DSM-5, diagnostic manual.

\section{Current Death Row Inmates}

In Oregon currently there are 24 people on death row (NAACP Legal Defense and Educational Fund, Inc., 2020). A few years ago, there were 33 people sentenced to die in Oregon (Criminal Justice Project, 2018), however with the Senate Bill 1013 in 2019 which severely limited the crimes eligible to receive a capital sentence that number has dropped significantly due to resentencing. To be able to decide whether the current laws in Oregon - Guilty Except for 
Insanity statute and mitigating factors - are actually working in the State of Oregon to protect those with severe mental illnesses the author has looked at all current death row inmate's cases to be able to draw a conclusion. There were seven death row inmates that the author found problematic in regards to their current sentence. Below is a short summary of each of the seven inmates focusing not on their crimes but their mental states and potential illnesses, followed by a discussion on the author's reasoning and suggestions.

David Ray Bartol was sentenced to death in Oregon in 2016 for being found guilty on 24 accounts including aggravated murder committed while in prison. As per the ORS 161.095 (see Appendix A) an incarcerated prisoner qualifies for the death penalty if he commits murder while incarcerated. According to the report of the Oregonian Bartol's defense attorney argued that Bartol had below-average IQ resulting from fetal alcohol syndrome which has resulted in inadmissible evidence during police questioning (Green, 2016). Fetal alcohol syndrome is caused by the mother consuming alcohol and drugs during pregnancy resulting in limited mental capacities, no concept of risk, being physically brutal, difficulty empathizing, and being prone to bragging. His condition went undiagnosed for a while and resulted in him falling behind in school and also led him to start using drugs. Later in his life, he has received several different mental health diagnoses ranging from obsessive-compulsive disorder to sociopathy (Woodworth, 2016).

Bartol's case presents a couple problems. First, he was assessed to be below average IQ and while there is no exact score available, they put him somewhere between 55 and 96 which could potentially qualify him for an intellectual disability defense which was not pursued by his defense (Green, 2016). Furthermore, his fetal alcohol syndrome has a symptom that makes him prone to bragging which resulted in inadmissible evidence that should not have been used during the trials according to his defense. While fetal alcohol syndrome and obsessive-compulsive personality disorders are not protected under the insanity defense in Oregon, they do have symptoms that should have been better utilized as mitigating evidence and should not have been used by the prosecution to argue for future dangerousness as aggravating factors.

Clinton Cunningham was sentenced to death in 1992 for the aggravated murder of a 19 years old female hitchhiker (Blanco, 2017a). He was diagnosed during his trial with antisocial personality disorder and potentially sadistic personality disorder. The court psychologist also testified that Cunningham was also suffering from organic personality syndrome. Organic personality syndrome makes it hard to control one's behavior and can lead to outbursts of anger. The court psychologist noted that these are hard to treat conditions and best is to provide a highly structured environment to a person suffering from them.

In Cunningham's case his personality disorders were used in the court's and jury's analysis of future dangerousness when making a sentencing decision. With one of the most recent changes to Oregon's death penalty statute (S.B. 1013, 2019) imposed by Oregon's current governor Kate Brown, Cunningham's sentence would no longer uphold. Under the revised death penalty statute only three aggravating circumstances stay in place and the future dangerousness assessment is no longer a part of it. The effect of future dangerousness has played a huge part in Cunningham's sentencing decision. However, the changes imposed on the statute do not work retroactively, they can only be applied to future cases. This is especially problematic considering that the future dangerousness assessment involved arguments from the prosecution that targeted symptoms of Cunningham's personality disorders. While these do not qualify him for the insanity defense they should still only be used as mitigating factors rather than aggravating considering they are related to a mental illness. 
Robert Langley has two death sentences for two separate murders he committed in the late ' 80 s and was last sentenced to die in 2006 (Blanco, 2017b). His sentence was overturned several times by the Oregon Supreme Court, however currently he is serving on death row. He was in a residential Criminal Treatment Program designed for mentally and emotionally disabled inmates when he committed his second murder on the grounds of the Oregon State Mental Hospital. According to Langley's appeals his case has included privileged conversations as evidence; however, the court's argument was that he waived his right to invoke that exclusion on the materials in question. During Langley's case the trial instructions included that when the jury determines the potential threat, he would pose to society in the future to consider his mental and emotional health and tendencies stemming from that (State v. Langley, 1992).

Robert Langley's case is another example of the insanity defense failing to provide protection to someone with a mental illness. He committed his second murder while being in a residential treatment program for mentally and emotionally disabled inmates so it was already acknowledged that he has some sort of mental illness. As stated above there were privileged conversations included as evidence against Langley during his trial. From a strictly legal standpoint this is not surprising at all, however it is questionable how a mentally and emotionally disabled inmate can give up his rights to anything on their own. His case also involved the now outdated future dangerousness assessment as well which again was based on factors and symptoms stemming from his mental illness. As mentioned earlier mental illness is a mitigating evidence and using it or symptoms related to it to assess future dangerousness is using it as an aggravating factor (Berkman, 1989)

Marco Antonio Montez was sentenced to death in 1988 for the murder and rape of a 26 years old female (Blanco, 2017c). In his case and during his appeals process he argued that his

post-traumatic stress disorder stemming from childhood sexual abuse was not utilized by his defense attorney effectively as mitigating evidence (Marco Antonio Montez v. Stanley Czerniak, 2010). However, the Oregon Supreme Court so far has rejected this argument. The psychologist on the case has diagnosed Montez with post-traumatic stress disorder and battered child syndrome and also concluded that there was fetal alcohol and drug exposure that could have resulted in the defendant's substance use problems. Montez was also diagnosed with antisocialpersonality disorder. The prosecution has used this diagnosis as an aggravating factor arguing that it makes the defendant more prone to violence in the future. However, they noted that this could be effectively treated within the prison system (Montez v. Czerniak, 2014). Montez's case is another example of misusing mental illness and symptoms of mental illness as an aggravating factor by the prosecution. As the defendant's proneness to violence stems from his anti-social personality disorder it should have only been utilized as a mitigating factor.

Dayton Leroy Rogers received a death sentence in 1989 for the murder and rape of seven women, but he is thought to be responsible for more murders than that (State v. Rogers, 2000). He received multiple death sentences for his actions. Prior to his capital sentencing he had several charges dating all the way back when he was only 19. For many of his non murderous previous crimes at the time he received a not guilty by reason of insanity decision. He has tried to appeal and get his capital sentence overturned a few times with no luck. He was examined by psychologists and neurologists during his trial proceedings and those evaluations have shown brain damage in his frontal lobe that results in lost inhibitions, development of obsessivecompulsive and antisocial behaviors, and engagement in risk taking manic sprees (Bella, 2019). His brain tissue loss can lead to detachment and dissociative experiences. Some of this can be a 
result of his tumultuous childhood moving around a lot with a religious extremist family where he was abused and prohibited to make friends.

While Roger's case is truly disturbing as the only serial killer in Oregon's recent history it is clear from the evidence listed above that the insanity defense was not effectively utilized in his case. The most questionable part of his case is that he already had utilized the insanity defense in non-murderous crimes successfully, yet he was not able to do that for his murder charges. This makes it seem like there is a lack of standards surrounding the application of the insanity defense as it should not be possible for a defendant to qualify for it for some crimes but not others. Further problems are presented when taking a look at the fact that he was assessed by psychologists and neurologists for his murder trial and was deemed to have brain damage in his frontal lobe that led to behavioral and functional problems.

Eric Walter Running was convicted of the murder of two women and received the death penalty in 2000 (State v. Running, 2004). He killed his ex and her lover in a downtown restaurant. According to his defense and assessing psychologist he is thought to suffer from a dissociative disorder as a consequence of childhood trauma. He was adopted right after birth and never knew his mother. Later when he was a baby his adoptive mother who was a serious alcoholic had left the family. His adoptive father remarried but both him and the new mother were heavy drinkers and not a loving family. The defense argued in Running's case that he was under extreme emotional disturbance because of his dissociative disorder that resulted from cumulative trauma of rejection triggered by his ex leaving him. According to the defense Running displays several major symptoms of this disorder including dissociative amnesia, identity confusion and identity alteration. Running's case was reversed and remanded in 2020 on the basis of the defense failing to bring in an expert to assess future dangerousness (Running $v$ Kelly, 2020)

Matthew Dwight Thompson was sentenced to death in 1996 for stabbing two people to death (State v. Thompson, 1999). He was diagnosed with antisocial personality disorder with paranoid features and borderline personality disorder by psychologists and psychiatrists on his defense team. As noted earlier under Oregon statute this does not fall under a mental disease or defect to qualify for an insanity defense. Symptoms of these personality disorders include acting impulsively and overreacting perceived rejection with inappropriate displays of anger that are disproportionate. He also has a multi-generational family history of mental illness and substance abuse. He is claimed to have a traumatic childhood and an abusive marriage. He has filed an appeal in 2014 which included a segment focusing on missed relevant mental health and background information. Only after his initial trial did his defense team get a hold of records of past treatments of mental illness and developmental delay. The court has rejected this appeals argument on the basis that the question in place was whether "the trial counsel has exercised reasonable skill and judgment" and "is not whether the evidence could have been presented in a different way, or whether additional facts could have been included (Thompson v. Belleque, 2014)."

\section{Analysis}

All of these current Oregon death row cases described above presented some sort of issue related to the misuse or complete disregard of these defendants' mental illnesses during their trials and sentencing. These problems encompass a wide range of different aspects of the current death penalty scheme in Oregon. Some of the cases show a clear failure of the consistent application of the Guilty Except for Insanity exclusion of Oregon's criminal law. There seems to 
be some discrepancies in the application of the insanity defense in Oregon as described for example in Dayton Leroy Rogers' case. This is not surprising considering that research has shown it is extremely hard to rely on the protection of this type of defense (TASMIE, 2019). However, it is shocking that even when a defendant was able to utilize this defense in a prior case that does not automatically apply to future cases of theirs. It is one thing to not consistently apply the insanity defense across multiple different defendants, but to not apply it consistently for the same defendant makes it impossible to not question.

Looking at the other problems that can be observed in the cases of these seven death row inmates another big issue comes from the utilization of outdated sentencing decision factors. This is particularly true for the usage of the future dangerousness assessment (S.B. 1013, 2019). As stated above in 2019 Kate Brown has gotten rid of the future dangerousness assessment requirement when making sentencing decisions in criminal cases. While all of these cases were decided prior to that legal change in 2019 excluding that type of assessment, it is questionable how it could be fair if it is not applied retroactively as well so long there are still defendants affected by it. Not with standing it might make sense from a legal standpoint, from a humanitarian point of view not going back and correcting our mistakes when it could affect lives makes one question the morality of our legal processes.

However, even if we do not reevaluate these sentencing decisions on the basis of the laws changing these assessments of future dangerousness were still not in line with how mental illness should be utilized during trials. As stated, several times during this paper, mental illness should be only used as a mitigating factor and cannot be used as an aggravating one (Berkman, 1989; Task Force on Mental Disability and the Death Penalty, 2005; Gillespie et al., 2014). Many of these cases showcase a prosecutorial abuse on this limitation. The author has pointed out before and referenced relevant research that concluded this trend of symptoms of mental illness being incorrectly used by the prosecution and the findings here seem to support that idea. Most of the future dangerousness assessments mentioned in these cases were based on whether the jury deems the defendant aggressive and prone to violence completely ignoring the fact that those are symptoms of a mental illness in many cases (State v. Langley, 1992; State v. Cunningham, 1994; State v. Bartol, 2019). This is partially because the prosecution highlights the symptom only as a behavioral tendency conveniently leaving out the root of it; and partially because the jurors are uneducated or undereducated on the actual symptoms and nature of these disorders leaving them susceptible to the prosecutorial misrepresentation of them. Robert Langley's case is the best example of this as it was clearly stated in his case by the prosecution that the jury should consider his mental and emotional well-being when assessing future dangerousness (State $v$. Langley, 1992). It is not clear to the author of this paper how a statement like that was allowed in this case. Unfortunately, with the prosecution getting a chance at a final rebuttal argument during trial it is easy for them to highlight just the behavioral concerns to reinforce their own argument and perspective.

Finally, the last and probably biggest concern of the author is around how the Psychiatric Security Review Board made its decision as to what constitutes as a Qualifying Mental Disorder for the insanity defense (Psychiatric Security Review Board, n.d.). According to them they have based their definition around the American Psychiatric Association's (2013) Diagnostic and Statistical Manual of Mental Disorders ( $5^{\text {th }}$ ed.; DSM-5) but the disorders that qualify someone for the insanity defense are more in line with the American Psychiatric Association's (2000) Diagnostic and Statistical Manual of Mental Disorders (4 $4^{\text {th }}$ ed.-TR; DSM-4-TR) Axis I disorders differentiation. Axis I was based on what mental health professionals thought to be the most 
severe disorders in line with the wording of the Atkins v. Virginia (2002) holding in the Task Force on Mental Disability and the Death Penalty (2005) recommendation released by the ABA Section of Individual Right and Responsibilities. But even then, the Task Force Report included dissociative disorders in Axis I, yet in Oregon's Qualifying Metal Disorder statute there is no mention of dissociative disorders.

After Atkins v. Virginia in 2002 the ABA's Section of Individual Rights and Responsibilities has created a task force to define and create a more detailed guideline as to what constituted an exception under the Atkins (2002) holding (Task Force on Mental Disability and the Death Penalty, 2005). This has happened as they have felt the Court failed to create specific guidelines for the application of their decision. The taskforce was a collaborative effort of the ABA, American Psychological Association, American Psychiatric Association, and the National Alliance on Mental Illness including 24 mental health experts, psychologist, psychiatrist and legal personnel. The Task Force on Mental Disability and the Death Penalty defined what constituted a severe mental illness based on the DSM-IV-TR Axis I diagnosis specifications. Axis I diagnosis was considered the most severe disorders in the eyes of mental health professionals and it included psychotic disorders, mania, major depressive disorder and dissociative disorders (Task Force on Mental Disability and the Death Penalty, 2005). Personality disorders were categorized as Axis II disorders. On the other hand, in the DSM-V which was published first in 2013 there is no longer a multiaxial system of categorizing mental illnesses to simplify diagnosing. The change particularly involved getting rid of the differentiation between Axis I through III as there has been long standing arguments by experts that there is no fundamental difference across disorders on those axis'. With this change there are no longer distinct categories for mental health diagnosis, medical diagnosis, and personality disorders (Tobe, 2019).

However, even if the statute was based on the Axis categorizations of disorders as noted above with the release of the DSM- 5 there is no longer a multiaxial differentiation between certain disorders. This is particularly important as we can see that many of these death row inmates suffer from some type of personality disorder that severely affects their decision making and ability to interact with society. It makes sense based on the DSM-4-TR axis differentiation to exclude personality disorders as they used to be in Axis II and not considered the most severe of mental illnesses. But with the most recent changes to the Diagnostic Manual excluding personality disorder seems to have no psychological basis anymore.

On the other hand, in abnormal psychology there is a differentiation between egosyntonic and ego-dystonic disorders (Wikipedia, 2021). Most personality disorders are considered ego-syntonic disorders meaning that the person suffering from them is unable to recognize and acknowledge their own disorder and perceives their actions as normal. This often leads to victim blaming, which immediately negatively affects their perception by other people, in this case the jurors. Contrastingly, people with ego-dystonic disorders know their behavior is abnormal and it might even cause them great distress. This in the court room translates into affecting culpability and liability. Culpability or blameworthiness is the defendant understanding what they did was a crime. In criminal law it has four degrees, based on which sentencing options and severity vary. Liability is the condition of the defendant being responsible for the crime. From this we can see how ego-syntonic personality disorders can be found criminally more severely culpable. Then combined with a lack of remorse shown on the side of the defendant - as they are unaware of their disorder - leads them to being found more criminally 
liable and receiving a more severe sentence. According to the official statement of the American Bar Association in 2006 they oppose the death penalty for severe mental illnesses. The severity of a mental illness is then decided by the level of impairment it causes. Since personality disorders do not qualify as a severe mental illness in the legal sense to protect a defendant under the insanity defense we are left we no choice but to assume according to the American Bar Association a disorder that's symptoms include not being aware of said disorder is not severe enough to not be executed with.

This shows how ego-syntonic disorders almost instantly make you more morally culpable and criminally liable from a legal perspective. As mentioned most personality disorders are egosyntonic. This, taken together with how in light of the DSM-5 changes the qualifying mental disorder definition in Oregon does not have a psychological leg to stand on any longer when it leaves out personality disorders, means that the definition was created more in line with legal standards rather than psychological. It is hard to see however, how it is legally acceptable to punish someone for a disorder that does not allow the person suffering from it to even recognize their own illness. As stated earlier these disorders are like any other physical disorder, no one signed up for them and volunteered to have them. Yet, we created a society that punishes one for things completely outside of their control, that they cannot even see. It is even questionable whether these people would even recognize the disorder if they saw it.

If by now we have learned all this about the different psychological disorders over the past few decades, it is hard to say that our legal proceedings are based on precedent as they should be. In 1958 with the case of Trop v. Dulles (1958) the Court created a standards of decency test, according to which to interpret the Eight Amendment we "must draw its meaning from the evolving standards of decency that mark the progress of a maturing society." Since then the Court has applied the standards of decency test to many different ideas and cases. Relating to mental illness even though our society has clearly started to advocate for more focus on mental health and mental illness, our legal system does not seem to mark this progress of the maturing society. In regard to death penalty caselaw Furman v. Georgia (1972) established more guidance and less discretion in the application of death penalty laws. Later on, Gregg v. Georgia (1976) made reforms to establish more consistency in the application of capital sentencing. These two cases are examples of our society maturing beyond inconsistent applications of law. Unless we are inconsistently applying the standards of decency test which defeats the purpose of the Gregg (1976) decision. Either way it can be concluded that there is little to no consistency in the application of capital sentencing guidelines and laws. As a result of this inconsistency the failsafe's in place to protect the ones that are not the most deserving of the worst punishment like the insanity defense, or mitigating evidence are completely rendered useless and justice is not served.

\section{Discussion}

The death penalty supporters argue that capital sentencing ensures the ultimate punishment for the worst of crimes with retribution and deterrence (BBC, 2014). However, looking at the research and information presented here we can see that the data shows otherwise (Oregon Justice Resource Center, n.d.; Parks, 2019). In Oregon, many of the death row inmates have one or more issues including intellectual disability, severe childhood trauma, were barely adults when they committed their crime, or have a severe mental illness. As indicated in previous sections there is extensive research showing that individuals with severe mental illness should be excluded from receiving a death sentence (Augusta Free Press, 2018; Mangels, 2021; Task Force on Mental Disability and the Death Penalty, 2005). While Oregon has some safety guards in 
place to filter out the worst offenders and attempts to provide protection to mentally ill defendants the author's conclusion here is that the system is still failing (Oregon Criminal Justice Commission, n.d.; Psychiatric Security Review Board, n.d.).

With the lack of consistency applying the insanity defense and the extreme requirements to qualify someone for it (TASMIE, 2016) the Guilty Except for Insanity is not a substantial defense to protect the severely mentally ill. In line with the DSM-5 definitions ( $5^{\text {th }}$ ed.; DSM-5) there seems to be no logistical reason as to why only three disorders are included in the Qualifying Mental Disorder exclusion in Oregon. Even with looking at the Diagnostic Manual's older version there is no explanation why dissociative disorders were excluded bringing the whole statute in question (Psychiatric Review Board, n.d.). There were no available findings to the author regarding what logic the statute was based on. With the most recent changes in the Diagnostic Manual and the symptomatic definitions of personality disorders the author feels as though these types of disorders should also qualify a defendant to be excluded from the death penalty.

While the idea is that mental illness should only be used as a mitigating factor during sentencing decisions there is an overwhelming amount of evidence that there are not enough safeguards in place in Oregon to allow for that to actually happen (BBC, 2014). With mental illness not listed on Oregon's list of mitigating factors (Oregon Criminal Justice Commission, n.d.) - assuming the insanity defense to be considered sufficient protection - it leaves the door open for prosecutors to utilize behavioral symptoms of defendant's mental illnesses against them misleading the jury (Gillespie et al., 2014). According to the American Psychological Association even personality disorders have a genetic factor involved in their manifestation rendering the option of capital sentencing quite upsetting in these cases (Huff, 2004).

\section{Other Factors to Consider}

While mental illness is clearly a major unprotected issue in capital sentencing unfortunately there are a handful of other problems that are notable. The following factors all play into the decision-making process for sentencing decisions in capital cases. Some of these factors include the location of the crime, the quality of the defense, and even the race of both the perpetrator and the victim. Since 1973 over $75 \%$ of death row inmates victims were white (DPIC, 2021j), while nationally only 50\% of all murder victims are white. A 2014 study (Beckett, 2014) found that jurors in Washington state are three times more likely to recommend capital punishment for a black defendant than for a white defendant in similar cases. According to the United States Census Bureau's 2019 report 2.2\% of Oregon's population is African American (United States Census Bureau, 2019), while out of the 24 people currently with a death sentence in Oregon 2 of them are black, making the $8.3 \%$ of Oregon's death row population black (NAACP Legal Defense and Educational Fund, Inc., 2020).

Across the country, by now over 185 people have been exonerated from death row as they were found innocent (DPIC, 2021k, Equal Justice Initiative, 2021); however, no one has been exonerated in Oregon yet (Oregon Justice Resource Center, n.d.). While every system has its flaws, it is questionable whether risking an innocent person's life if they are not proven innocent in time is worth it just so we can punish the worst crimes with death. In 2016 the Lewis and Clark Law School and Seattle University conducted a study about the cost of death sentences in Oregon compared to life without the possibility of parole (Kaplan, Collins, \& Mayhew, 2016). This study found that legal fees alone cost up to a million dollars more than in non-capital cases. So even from a financial perspective only this does not seem like the most cost-effective way of 
punishing crimes. Studies have also shown that while originally the death penalty was instated to deter and reduce crime rates, its deterrent effect is non-existent (DPIC, 2021j).

\section{Solutions and Future Direction}

To protect the mentally ill from being executed and to only punish the worst offenders the State of Oregon should create a categorical ban on capital sentencing for severe mental illness. As the Guilty Except for Insanity defense is too narrow at its current definition it could be broadened to include more mental disorders and should be updated in line with the most recent changes to the Diagnostic Manual and the evolved opinions of mental health and legal professional organizations (Task Force on Mental Disability and the Death Penalty, 2005). Furthermore, Oregon should add not only severe but general mental illnesses to their list of mitigating factors. Leaving it off the official list leaves the door open to the prosecution to misuse symptomatic and behavioral evidence when presenting their case arguing for the most severe punishment (Berkman, 1989). Furthermore, when a defendant does have a mental illness as a mitigating factor, jurors should be provided information regarding what the symptoms of that mental illness is. This would reduce the chance of jurors mistakenly correlating mental illness with violent behavior as they frequently do so (Gillespie et al., 2014). In summary, creating more defined statutes excluding behavioral symptoms stemming from mental illnesses being used as an aggravating factor could prove beneficial. These changes could provide mentally ill defendants with more protection at the sentencing phase of their trial and would leave less room for different interpretations of the laws.

\section{Limitations}

There are several limitations to address in regard to this paper. The first major limitation of this research is that it only looked at current death row inmates and not all defendants that have at one point faced capital sentencing but did not receive it as punishment. Therefore, the author will not draw conclusions as to what percentage of the cases is severe mental illness a negative factor. Further limitations include the lack of access to actual case files. The author could draw conclusions only from what is available online regarding and about cases. This includes online libraries, journal articles, and websites with free access. Similar limitation comes from the fact that this paper was intended and is a meta-analysis, therefore, conclusions were only drawn from articles and laws and there were no human subjects or professionals contacted for more detailed information. This type of research automatically includes the potential for the biases of the researcher to be included. While the author is admittedly against the death penalty as a concept, serious attempts were made to balance that out with only considering cases that provided sufficient evidence that they could have qualified for a lesser sentence. Even then metaanalysis can include evidence that was thought to have more strength over another mistakenly and could potentially present evidence not as precise as other types of research. To balance this, attempts were made on the authors end to provide a wide variety of research findings mostly including research that was objective and neutral resource in their position on the death penalty. Conclusion

As findings in this paper show currently in Oregon there is not a sufficient enough protection provided to severely mentally ill defendants during capital trials. While the Qualifying Mental Disorder exclusion under the Guilty except for Insanity defense is a good start it is clearly shown to be not inclusive enough. With the severe limitations of only three qualifying disorders it renders some mentally ill defendants defenseless when they face the death penalty. The missing mitigating factor exclusion might even prose an even bigger threat to these 
THE EFFECTS OF MENTAL ILLNESS ON CAPITAL SENTENCING

defendants as it allows the prosecution to abuse the diagnosis of defendants making it

questionable whether the State of Oregon only reserves the death penalty for its worst offenders.
THE EFFECTS OF MENTAL ILLNESS ON CAPITAL SENTENCING

\section{References}

American Psychiatric Association. (2000). Diagnostic and statistical manual of mental disorders $\left(4^{\text {th }}\right.$ ed.-TR). Washington, DC: Author

American Psychiatric Association. (2013). Diagnostic and statistical manual of mental disorders (5 ${ }^{\text {th }}$ ed.). https://doi.org/10.1176/appi.books.9780890425596

American Psychiatric Association. (2018). What is mental illness?

https://www.psychiatry.org/patients-families/what-is-mental-illness

Atkins v. Virginia, 536 US 304 (2002). https://www.oyez.org/cases/2001/00-8452

Augusta Free Press. (2018, January 25). Prominent Virginia conservatives support severe mental illness exemption from death penalty. https://augustafreepress.com/prominent-virginiaconservatives-support-severe-mental-illness-exemption-death-penalty/

Ballotpedia. (n.d.a). Oregon death penalty for "Beyond reasonable doubt" murderers, Measure 8 (1978).

https://ballotpedia.org/Oregon_Death_Penalty_for_\%22Beyond_Reasonable_Doubt\%22 Murderers,_Measure_8_(1978)

Ballotpedia. (n.d.b). Oregon death penalty for aggravated murder, Measure 7 (1984).

https://ballotpedia.org/Oregon_Death_Penalty_for_Aggravated_Murder,_Measure_7_(19 84)

Balmert, J., (2020, December 9). Ohio could soon exempt killers with serious mental illnesses from the death penalty. Cincinnati Enquirer.

https://www.cincinnati.com/story/news/politics/2020/12/09/ohio-could-soon-exempt-

killers-serious-mental-illnesses-death-penalty/3793903001/

BBC. (2014). Argument in favor of capital punishment. Retrieved May 12, 2021, from 
https://www.bbc.co.uk/ethics/capitalpunishment/for_ 1 shtml

Beckett, K. (2014). The role of race in Washington state capital sentencing, 1981-2014.

https://files.deathpenaltyinfo.org/legacy/documents/WashRaceUPDATE.pdf

Bedau, H. A. (1998). The death penalty in America: Current controversies. Oxford University

Press. https://global.oup.com/academic/product/the-death-penalty-in-america-

9780195122862 ?cc $=$ us\&lang $=$ en $\&$

Beitsch, R. (2017, April 17). States consider barring death penalty for severely mentally ill.

Pew Stateline. https://www.pewtrusts.org/en/research-and-

analysis/blogs/stateline/2017/04/17/states-consider-barring-death-penalty-for-severelymentally-ill

Bella, R. (2019, January 9). Defense says serial killer Dayton Leroy Rogers has brain damage, doesn't deserve death penalty. Oregon Live/The Oregonian.

https://www.oregonlive.com/oregon-city/2015/11/defense_says_serial_killer_day.html Berkman, E. F. (1989). Mental illness as an aggravating circumstance in capital sentencing.

Columbia Law Review, 89(2), 291. doi: 10.2307/1122823

Blanco, J. I. (2017a). Clinton Wendall Cunningham. Murderpedia.

https://murderpedia.org/male.C/c/cunningham-clinton.htm

Blanco, J. I. (2017b). Robert Paul Langley Jr. Murdepedia.

https://murderpedia.org/male.L///langley-robert.htm

Blanco, J. I. (2017c). Marco Antonio Montez. Murderpedia.

https://murderpedia.org/male.M/m/montez-marco-antonio.htm

Bohm, R. M. (1999). Deathquest: An introduction to the theory and practice of capital punishment in the United States. Anderson Publishing Co https://www.ojp gov/ncjrs/virtual-library/abstracts/deathquest-introduction-theory-and-

practice-capital-punishment

Coker v. Georgia, 433 US 584 (1977). https://www.oyez.org/cases/1976/75-5444

Criminal Justice Project. (2018, July 1). Death row U.S.A. Summer 2018. NAACP Legal Defense and Educational Fund, Inc.

https://files.deathpenaltyinfo.org/legacy/documents/DRUSASummer2018.pdf

Crombie, N. (2020, May 15). Oregon's death row will be dismantled by summer. The

Oregonian. https://www.oregonlive.com/crime/2020/05/oregons-death-row-will-be-

dismantled-by-summer.html

Crombie, N. (2020, June 19). State clearing out death row. East Oregonian.

https://www.eastoregonian.com/news/state/state-clearing-out-death-

row/article_14e2a10c-b235-11ea-b303-77e65c8ab0f6.html

Davis, E., \& Snell, T. L. (2018). Capital punishment, 2016 [Statistical Brief]. U. S. Department of Justice, Office of Justice Programs. https://www.bjs.gov/content/pub/pdf/cp16sb.pdf

Death Penalty Information Center. (2021a). State by state. Retrieved April 10, 2021, from https://deathpenaltyinfo.org/state-and-federal-info/state-by-state

Death Penalty Information Center. (2021b). Summary of state death penalty statutes. Retrieved April 10, 2021, from https://deathpenaltyinfo.org/facts-and-research/crimes-punishableby-death/summary-of-state-death-penalty-statutes

Death Penalty Information Center. (2021c). Crimes punishable by death. Retrieved April 10, 2021, from https://deathpenaltyinfo.org/facts-and-research/crimes-punishable-by-death

Death Penalty Information Center. (2021d). Conditions on death row. Retrieved April 10, 2021, from https://deathpenaltyinfo.org/death-row/conditions-on-death-row 
Death Penalty Information Center. (2021e). Time on death row. Retrieved April 10, 2021, from https://deathpenaltyinfo.org/death-row/death-row-time-on-death-row

Death Penalty Information Center. (2021f). Constitutionality of the death penalty in America.

Retrieved April 10, 2021, from https://deathpenaltyinfo.org/facts-and-research/history-ofthe-death-penalty/constitutionality-of-the-death-penalty-in-america

Death Penalty Information Center. (2021g). State and federal info - Oregon. Retrieved October 3, 2020, from https://deathpenaltyinfo.org/state-and-federal-info/state-by-state/oregon Death Penalty Information Center. (2021h). Oregon closes death row, joins national trend away from automatic solitary confinement. Retrieved April 11, 2021, from https://deathpenaltyinfo.org/news/oregon-closes-death-row-joins-national-trend-awayfrom-automatic-solitary-confinement

Death Penalty Information Center. (2021i). Recent legislative activity. Retrieved April 18, 2021 from https://deathpenaltyinfo.org/facts-and-research/recent-legislative-activity

Death Penalty Information Center. (2021j). Facts about the death penalty. Retrieved April 18, 2021 from https://documents.deathpenaltyinfo.org/pdf/FactSheet.pdf

Death Penalty Information Center. (2021k). Innocence database. Retrieved May 12, 2021 from https://deathpenaltyinfo.org/policy-issues/innocence-

database?filters $\% 5$ Bstate $\% 5 \mathrm{D}=$ =regon

DeMatteo, D. (2017, September). Limiting the reach of the death penalty. Monitor on

Psychology, 48(8). http://www.apa.org/monitor/2017/09/jn

Department of Corrections. (2021). Oregon death penalty. Retrieved October 3, 2020, from https://www.oregon.gov/doc/about/Pages/oregon-death-penalty.aspx

Equal Justice Initiative. (2021). Death penalty innocence and error. Retrieved May 12, 2021, from https://eji.org/issues/death-penalty/

Ford v. Wainwright, 477 US 399 (1986). https://www.oyez.org/cases/1985/85-5542 Furman v. Georgia, 408 U.S. 238 (1972). https://www.oyez.org/cases/1971/69-5030 Gillespie, L. K., Smith, M. D., Bjerregaard, B., \& Fogel, S. J. (2014). Examining the impact of proximate culpability mitigation in capital punishment sentencing recommendations: The influence of mental health mitigators. American Journal of Criminal Justice, 39(4), 698-715. doi: 10.1007/s12103-014-9255-5

Green, A. (2016, September 6). 'Krude Rude Brood' gangster gets 55 years for sanding off tattoo, nearly killing men. Oregon Live/The Oregonian.

https://www.oregonlive.com/portland/2016/09/jury_man_guilty_of_all_counts.html Gregg v. Georgia, 428 US 153 (1976). https://www.oyez.org/cases/1975/74-6257

Horner, J. B., (1919). Oregon: Her history, her great men, her literature. Press of the Gazette Times

Huff, C. (2004, March). Personality disorders: Where personality goes awry. Monitor on Psychology, 35(3). http://www.apa.org/monitor/mar04/awry

Kaplan, A. B., Collins, P. A., \& Mayhew, V. L. (2016). Oregon's death penalty: A cost analysis. Oregon Justice Resource Center. https://law.lclark.edu/live/files/22888oregons-death-penalty-a-cost-analysis-2016

Lockett v. Ohio, 438 US 586 (1978). https://www.oyez.org/cases/1977/76-6997

Madison v. Alabama, 586 US _ (2019). https://www.oyez.org/cases/2018/17-7505

Mangels, A.T. (2021, March 19). Severe mental illness initiative. American Bar Association.

https://www.americanbar.org/groups/crsj/projects/death_penalty_due_process_review_pr oject/severe-mental-illness-initiative/ 
Marco Antonio Montez v. Stanley Czerniak, 237 Or. App. 276 (Or. Ct. App. 2010). https://caselaw.findlaw.com/or-court-of-appeals/1539001.html Montez v. Czerniak, 355 Or. 1, 7, 322 P.3d 487 (2014). https://casetext.com/case/montez-vczerniak-3/case-details?PHONE_NUMBER_GROUP=P

NAACP Legal Defense and Educational Fund, Inc. (2020, October 1). Death row U.S.A. Fall 2020. https://www.naacpldf.org/wp-content/uploads/DRUSAFall2020.pdf National Alliance on Mental Illness. (n.d.). Individuals with mental illness.

https://www.nami.org/Your-Journey/Individuals-with-Mental-Illness National Institute of Mental Health. (January 2021). Mental illness.

https://www.nimh.nih.gov/health/statistics/mental-illness\#part_154910

OR. Const. art. I, $\S 40$.

Oregon Criminal Justice Commission. (n.d.). State archives, Chapter 213 Division 8 Departures.

Oregon State Legislature. Retrieved April 18, 2021, from

https://secure.sos.state.or.us/oard/viewSingleRule.action?ruleVrsnRsn=265531 Oregon Justice Resource Center. (n.d.). Death penalty. Retrieved May 12, 2021, from https://ojrc.info/death-penalty

Oregon State Legislature. (2021). 2021 Regular session. Retrieved April 18, 2021, from https://www.oregonlegislature.gov/bills_laws/listbills/CurrentSessionBills.html

Panetti v. Quarterman, 551 US 930 (2007). https://www.oyez.org/cases/2006/06-6407

Parekh, R. (2018). What is mental illness? American Psychological Association.

https://www.psychiatry.org/patients-families/what-is-mental-illness

Parks, C. (2019, January 9). Most Oregon death row inmates suffer significant mental

impairments, Harvard report finds. Oregon Live/The Oregonian. https://www.oregonlive.com/pacific-northwest-

news/2016/12/most_oregon_death_row_inamtes.html

Penry v. Lynaugh, 492 US 302 (1989). https://www.oyez.org/cases/1988/87-6177

Psychiatric Security Review Board. (n.d.). State archives, Chapter 859, Division 10 Adult

Psychiatric Security Review Board Definitions. Oregon State Legislature. Retrieved April 18, 2021, from

https://secure.sos.state.or.us/oard/displayDivisionRules.action?selectedDivision=4001

Randa, L. E. (1997). Society's final solution: A history and discussion of the death penalty.

University Press of America.

https://www.ojp.gov/ncjrs/virtual-library/abstracts/societys-final-solution-history-anddiscussion-death-penalty

Romano, M. G. (2021). Oregon sentencing mitigating and aggravating factors. Romano Law

P.C. Retrieved April 18, 2021, from https://romanolawpc.com/mitigating-and-

aggravating-factors-under-oregon-sentencing-guidelines/

Roper v. Simmons, 543 US 551 (2005). https://www.oyez.org/cases/2004/03-633

Running v. Kelly, 306 Or. App. 589 (Or. Ct. App. 2020).

https://law.justia.com/cases/oregon/court-of-appeals/2020/a163582.html

S.B. 1013, $80^{\text {th }}$ Oregon Legislative Assembly, 2019 Regular Session. (Oregon, 2019).

https://olis.leg.state.or.us/liz/2019R1/Downloads/MeasureDocument/SB1013/Enrolled Schabas, W. A. (2002). The abolition of the death penalty in international law.

Cambridge University Press. https://doi.org/10.1017/CBO9780511494109 Skipper v. North Carolina, 476 US 1 (1986). https://www.oyez.org/cases/1985/84-6859 Smith, R. (2014). National death penalty survey results, November 24-25, 2014 [Data set]. 
Public Policy Polling.

https://drive.google.com/file/d/0B1LFfr8Iqz_7R3dCM2VJbTJiTjVYVDVodjVVSTNJb HgxZWlB/view

State v. Bartol, 442 P.3d 1117 (2019).

https://web.courts.oregon.gov/records/sccalendar.nsf/b29dd44d01dffea088256c91005b3a 5b/141cbafdc6c829d288258410007f3498?OpenDocument

State v. Cunningham, 320 Or. 47 (Or. 1994). https://casetext.com/case/state-v-cunningham-

144?q=state $\% 20 \mathrm{v} \% 20$ cunningham $\% 201992 \& \mathrm{p}=1 \&$ tab=keyword\&jxs=or\&sort=relevanc e\&type $=$ case

State v. Langley, 839 P.2d 692 (1992). https://law.justia.com/cases/oregon/supremecourt/1992/314-or-247.html

State v. Rogers, 529 S.E.2d 671 (2000). https://casetext.com/case/state-v-rogers-474/casedetails?PHONE_NUMBER_GROUP=P

State v. Running, 336 Or. 545 (Or. 2004). https://caselaw.findlaw.com/or-supremecourt/1419127.html

State v. Thompson, 328 Or. 248, 257, 971 P.2d 879 (1999). https://casetext.com/case/state-vthompson-

1182 ? $\mathrm{q}=\mathrm{state} \% 20 \mathrm{v} . \% 20$ thompson\&PHONE_NUMBER_GROUP=P\&sort=relevance\&p $=1 \&$ type $=$ case $\& j x s=$ or

Task Force on Mental Disability and the Death Penalty. (2005). Report of the Task force on mental disability and the death penalty. https://www.apa.org/pubs/info/reports/mentaldisability-and-death-penalty.pdf

Terry, J. (2005, November 6). Oregon's trails - 'Necktie parties' Does justice to legal hangings in Oregon. The Oregonian.

The Tennessee Alliance for the Severe Mental Illness Exclusion. (2016). Film tool kits. Retrieved April 18, 2021, from https://tasmie.org/film-tool-kits/

The Tennessee Alliance for the Severe Mental Illness Exclusion. (2019, February

10). Too ill to execute--32 Minute longest version [Video]. YouTube.

https://www.youtube.com/watch?v=uZNI8WoCSDY\&ab_channel=TASMIE

The United States Department of Justice. (July 1, 2021). Attorney General Merrick B. Garland Imposes a Moratorium on Federal Executions; Orders Review of Policies and Procedures. https://www.justice.gov/opa/pr/attorney-general-merrick-b-garland-imposesmoratorium-federal-executions-orders-review

Thompson v. Belleque, 268 Or. App. 1 (Or. Ct. App. 2014). https://casetext.com/case/thompsonv-belleque-

1?PHONE_NUMBER_GROUP=P\&sort=relevance $\&$ type $=$ case $\& j x s=$ or $\&$ resultsNav $=$ fals $\mathrm{e} \& \mathrm{tab}=$ keyword

Tobe, H. (2019, September 27). DSM-5: No more multiaxial system. Therapist Development Center. https://www.therapistdevelopmentcenter.com/blog/dsm-v-no-more-multiaxialsystem

United States Census Bureau. (2019). Quick facts Oregon. https://www.census.gov/quickfacts/OR

VanderHart, D. (2019, August 1). Gov. Kate Brown signs bill narrowing Oregon death penalty. OPB. https://www.opb.org/news/article/death-penalty-oregon-bill-signed-katebrown/

Wikipedia. (2021, January 1). Egosyntonic and egodystonic. Retrieved on July 18, 2021 from 
THE EFFECTS OF MENTAL ILLNESS ON CAPITAL SENTENCING

https://en.wikipedia.org/wiki/Egosyntonic_and_egodystonic

Woodworth, W. M. (2016, November 10). Man sentenced to death for fatally stabbing inmate at Marion County jail. Statesman Journal.

https://www.statesmanjournal.com/story/news/crime/2016/11/10/man-sentenced-deathfatally-stabbing-inmate-marion-county-jail/93616564

Zant v. Stephens, 462 US 862 (1983). https://www.oyez.org/cases/1982/81-89
THE EFFECTS OF MENTAL ILLNESS ON CAPITAL SENTENCING

Appendix A

\section{ORS 163.095 “Aggravated Murder” Defined}

As used in ORS 163.105 (Sentencing options for aggravated murder) and this section, "aggravated murder" means:

(1)Criminal homicide of two or more persons that is premeditated and committed intentionally and with the intent to:

(a)Intimidate, injure or coerce a civilian population

(b)Influence the policy of a government by intimidation or coercion; or

(c)Affect the conduct of a government through destruction of property, murder

kidnapping or aircraft piracy; or

(2)Murder in the second degree, as defined in ORS 163.115 (Murder in the second degree), that is:

(a)(A) Committed while the defendant was confined in a state, county or municipal penal or correctional facility or was otherwise in custody; and

(B)Committed after the defendant was previously convicted in any jurisdiction of any homicide, the elements of which constitute the crime of aggravated murder under this section or murder in the first degree under ORS 163.107 (Murder in the first degree);

(b)Premeditated and committed intentionally against a person under 14 years of

age;

(c)Premeditated, committed intentionally against a police officer as defined in

ORS 801.395 ("Police officer"), and related to the performance of the victim's official duties; or 
THE EFFECTS OF MENTAL ILLNESS ON CAPITAL SENTENCING

(d)Premeditated, committed intentionally against a correctional, parole and probation officer or other person charged with the duty of custody, control or supervision of convicted persons, and related to the performance of the victim's official duties. [1977 c. 370 §1; 1981 c. $873 \S 1 ; 1991$ c.742 §13; 1991 c. $837 \S 12 ; 1993$ c. $185 \$ 20 ; 1993$ c.623 §2; 1997 c.850 §1; 2005 c.264 §17; 2012 c.54 §26; 2015 c.614 §149; 2019 c.635 §1]
THE EFFECTS OF MENTAL ILLNESS ON CAPITAL SENTENCING

\section{Appendix B}

ORS 163.105 Sentencing Options for Aggravated Murder

Notwithstanding the provisions of ORS chapter 144 and ORS 421.450 (Definitions for ORS 421.455 to 421.480 ) to 421.490 (Work camps):

(1)(a) Except as otherwise provided in ORS 137.707 (Mandatory minimum sentences for certain juvenile offenders waived to adult court), when a defendant is convicted of aggravated murder as defined by ORS 163.095 ("Aggravated murder" defined), the defendant shall be sentenced, pursuant to ORS 163.150 (Sentencing for aggravated murder), to death, life imprisonment without the possibility of release or parole or life imprisonment.

(b)A person sentenced to life imprisonment without the possibility of release or parole under this section shall not have that sentence suspended, deferred or commuted by any judicial officer, and the State Board of Parole and Post-Prison Supervision may not parole the prisoner nor reduce the period of confinement in any manner whatsoever The Department of Corrections or any executive official may not permit the prisoner to participate in any sort of release or furlough program.

(c)If sentenced to life imprisonment, the court shall order that the defendant shall be confined for a minimum of 30 years without possibility of parole or release to postprison supervision except as provided in ORS 144.397 (Release eligibility for juvenile offenders after 15 years of imprisonment), and without the possibility of release on work release or any form of temporary leave or employment at a forest or work camp.

(2)At any time after completion of a minimum period of confinement pursuant to subsection (1)(c) of this section, the State Board of Parole and Post-Prison Supervision, upon the petition of a prisoner so confined, shall hold a hearing to determine if the prisoner is likely to be 
rehabilitated within a reasonable period of time. The sole issue is whether or not the prisoner is likely to be rehabilitated within a reasonable period of time. At the hearing, the prisoner has:

(a)The burden of proving by a preponderance of the evidence the likelihood of rehabilitation within a reasonable period of time;

(b)The right, if the prisoner is without sufficient funds to employ an attorney, to be represented by legal counsel, appointed by the board, at board expense; and

(c)The right to a subpoena upon a showing of the general relevance and reasonable scope of the evidence sought, provided that any subpoena issued on behalf of the prisoner must be issued by the State Board of Parole and Post-Prison Supervision pursuant to rules adopted by the board.

(3)If, upon hearing all of the evidence, the board, upon a unanimous vote of three board members or, if the chairperson requires all voting members to participate, a unanimous vote of all voting members, finds that the prisoner is capable of rehabilitation and that the terms of the prisoner's confinement should be changed to life imprisonment with the possibility of parole, release to post-prison supervision or work release, it shall enter an order to that effect and the order shall convert the terms of the prisoner's confinement to life imprisonment with the possibility of parole, release to post-prison supervision or work release and may set a release date. Otherwise the board shall deny the relief sought in the petition.

(4)If the board denies the relief sought in the petition, the board shall determine the date of the subsequent hearing, and the prisoner may petition for an interim hearing, in accordance with ORS 144.285 (Hearing after petition for change in terms of confinement denied to prisoner convicted of aggravated murder or murder).
(5)The board's final order shall be accompanied by findings of fact and conclusions of law. The findings of fact shall consist of a concise statement of the underlying facts supporting the findings as to each contested issue of fact and as to each ultimate fact required to support the board's order. [1977 c. 370 §2; 1981 c. 873 \$; 1985 c.3 §1; 1987 c. 158 §23; 1987 c.803 §20; 1989 c. 720 §1; 1991 c. $126 \S 8 ; 1995$ c.421 §2; 1999 c. 59 §31; 1999 c. $782 \S 5 ; 2007$ c.717 §1; 2009 c. $660 \$ 6 ; 2015$ c. $820 \$ 45 ; 2019$ c. $634 \$ 27]$ 


\section{Appendix C}

ORS 163.150 Sentencing for Aggravated Murder

(1)(a) Upon a finding that the defendant is guilty of aggravated murder, the court, except as otherwise provided in subsection (3) of this section, shall conduct a separate sentencing proceeding to determine whether the defendant shall be sentenced to life imprisonment, as described in ORS 163.105 (Sentencing options for aggravated murder) (1)(c), life imprisonment without the possibility of release or parole, as described in ORS 163.105 (Sentencing options for aggravated murder) (1)(b), or death. The proceeding shall be conducted in the trial court before the trial jury as soon as practicable. If a juror for any reason is unable to perform the function of a juror, the juror shall be dismissed from the sentencing proceeding. The court shall cause to be drawn the name of one of the alternate jurors, who shall then become a member of the jury for the sentencing proceeding notwithstanding the fact that the alternate juror did not deliberate on the issue of guilt. If the defendant has pleaded guilty, the sentencing proceeding shall be conducted before a jury impaneled for that purpose. In the proceeding, evidence may be presented as to any matter that the court deems relevant to sentence including, but not limited to, victim impact evidence relating to the personal characteristics of the victim or the impact of the crime on the victim's family and any aggravating or mitigating evidence relevant to the issue in paragraph (b)(C) of this subsection; however, neither the state nor the defendant shall be allowed to introduce repetitive evidence that has previously been offered and received during the trial on the issue of guilt. The court shall instruct the jury that all evidence previously offered and received may be considered for purposes of the sentencing hearing. This paragraph shall not be construed to authorize the introduction of any evidence secured in violation of the Constitution of the United States or of the State of Oregon. The state and the defendant or the counsel of the defendant shall be permitted to present arguments for or against a sentence of death and for or against a sentence of life imprisonment with or without the possibility of release or parole.

(b)Upon the conclusion of the presentation of the evidence, the court shall submit the following issues to the jury:

(A)Whether the conduct of the defendant that caused the death of the deceased was committed deliberately and with the reasonable expectation that death of the deceased or another would result;

(B)If raised by the evidence, whether the conduct of the defendant in killing the deceased was unreasonable in response to the provocation, if any, by the deceased; and

(C)Whether the defendant should receive a death sentence.

(c)(A) The court shall instruct the jury to consider, in determining the issues in paragraph (b) of this subsection, any mitigating circumstances offered in evidence, including but not limited to the defendant's age, the extent and severity of the defendant's prior criminal conduct and the extent of the mental and emotional pressure under which the defendant was acting at the time the offense was committed.

(B)The court shall instruct the jury to answer the question in paragraph (b)(C) of this subsection "no" if, after considering any aggravating evidence and any mitigating evidence concerning any aspect of the defendant's character or background, or any circumstances of the offense and any victim impact evidence as described in paragraph (a) of this subsection, one or more of the jurors believe that the defendant should not receive a death sentence. 
(d)The state must prove each issue submitted under paragraph (b) of this subsection beyond a reasonable doubt, and the jury shall return a special verdict of "yes" or "no" on each issue considered.

(e)The court shall charge the jury that it may not answer any issue "yes," under paragraph (b) of this subsection unless it agrees unanimously.

(f)If the jury returns an affirmative finding on each issue considered under paragraph (b) of this subsection, the trial judge shall sentence the defendant to death. (2)(a) Upon the conclusion of the presentation of the evidence, the court shall also instruct the jury that if it reaches a negative finding on any issue under subsection (1)(b) of this section, the trial court shall sentence the defendant to life imprisonment without the possibility of release or parole, as described in ORS 163.105 (Sentencing options for aggravated murder) (1)(b), unless 10 or more members of the jury further find that there are sufficient mitigating circumstances to warrant life imprisonment, in which case the trial court shall sentence the defendant to life imprisonment as described in ORS 163.105 (Sentencing options for aggravated murder) (1)(c).

(b)If the jury returns a negative finding on any issue under subsection (1)(b) of this section and further finds that there are sufficient mitigating circumstances to warran life imprisonment, the trial court shall sentence the defendant to life imprisonment in the custody of the Department of Corrections as provided in ORS 163.105 (Sentencing options for aggravated murder) (1)(c)

(3)(a) When the defendant is found guilty of aggravated murder, and ORS 137.707

(Mandatory minimum sentences for certain juvenile offenders waived to adult court) (2) applies or the state advises the court on the record that the state declines to present evidence for purposes of sentencing the defendant to death, the court:

(A)Shall not conduct a sentencing proceeding as described in subsection (1) of this section, and a sentence of death shall not be ordered.

(B)Shall conduct a sentencing proceeding to determine whether the defendant shall be sentenced to life imprisonment without the possibility of release or parole as described in ORS 163.105 (Sentencing options for aggravated murder) (1)(b) or life imprisonment as described in ORS 163.105 (Sentencing options for aggravated murder) (1)(c). If the defendant waives all rights to a jury sentencing proceeding, the court shall conduct the sentencing proceeding as the trier of fact. The procedure for the sentencing proceeding, whether before a court or a jury, shall follow the procedure of subsection (1)(a) of this section, as modified by this subsection. In the proceeding, evidence may be presented as to any matter that the court deems relevant to sentence, including, but not limited to, victim impact evidence relating to the personal characteristics of the victim or the impact of the crime on the victim's family.

(b)Following the presentation of evidence and argument under paragraph (a) of this subsection, the court shall instruct the jury that the trial court shall sentence the defendant to life imprisonment without the possibility of release or parole as described in ORS 163.105 (Sentencing options for aggravated murder) (1)(b), unless after considering all of the evidence submitted, 10 or more members of the jury find there are sufficient mitigating circumstances to warrant life imprisonment with the possibility of parole as described in ORS 163.105 (Sentencing options for aggravated murder) (1)(c). If 10 or 
THE EFFECTS OF MENTAL ILLNESS ON CAPITAL SENTENCING

more members of the jury find there are sufficient mitigating circumstances to warrant

life imprisonment with the possibility of parole, the trial court shall sentence the

defendant to life imprisonment as described in ORS 163.105 (Sentencing options for aggravated murder) (1)(c).

(c)Nothing in this subsection shall preclude the court from sentencing the defendant to life imprisonment, as described in ORS 163.105 (Sentencing options for aggravated murder) (1)(c), or life imprisonment without the possibility of release or parole, as described in ORS 163.105 (Sentencing options for aggravated murder) (1)(b), pursuant to a stipulation of sentence or stipulation of sentencing facts agreed to and offered by both parties if the defendant waives all rights to a jury sentencing proceeding. (4)If any part of subsection (2) of this section is held invalid and as a result thereof a defendant who has been sentenced to life imprisonment without possibility of release or parole will instead be sentenced to life imprisonment in the custody of the Department of Corrections as provided in ORS 163.105 (Sentencing options for aggravated murder) (2), the defendant shall be confined for a minimum of 30 years without possibility of parole, release on work release or any form of temporary leave or employment at a forest or work camp. Subsection (2) of this section shall apply only to trials commencing on or after July 19, 1989.

(5)Notwithstanding subsection (1)(a) of this section, if the trial court grants a mistrial during the sentencing proceeding, the trial court, at the election of the state, shall either:

(a)Sentence the defendant to imprisonment for life in the custody of the

Department of Corrections as provided in ORS 163.105 (Sentencing options for aggravated murder) (1)(c); or
THE EFFECTS OF MENTAL ILLNESS ON CAPITAL SENTENCING

(b)Impanel a new sentencing jury for the purpose of conducting a new sentencing proceeding to determine if the defendant should be sentenced to:

(A)Death;

(B)Imprisonment for life without the possibility of release or parole as provided in ORS 163.105 (Sentencing options for aggravated murder) (1)(b); or

(C)Imprisonment for life in the custody of the Department of Corrections as provided in ORS 163.105 (Sentencing options for aggravated murder) (1)(c). [1985 c.3 §3; 1987 c.320 §86; 1987 c.557 §1; 1989 c.720 §2; 1989 c.790 §135b; 1991 c. 725 §2; 1991 c.885 §2; 1995 c.531 §2; 1995 c.657 §23; 1997 c.784 §1; 1999 c. 1055 §1; 2001 c.306 §1; 2005 c.480 §1; 2017 c.359 §4; 2019 c.635 §5] 
THE EFFECTS OF MENTAL ILLNESS ON CAPITAL SENTENCING

\section{Appendix D}

\section{ORS 161.295 Effect of Qualifying Mental Disorder}

(1)A person is guilty except for insanity if, as a result of a qualifying mental disorder at the time of engaging in criminal conduct, the person lacks substantial capacity either to appreciate the criminality of the conduct or to conform the conduct to the requirements of law.

(2)As used in chapter 743, Oregon Laws 1971, the term "qualifying mental disorder" does not include an abnormality manifested only by repeated criminal or otherwise antisocial conduct, nor does the term include any abnormality constituting solely a personality disorder. [1971 c.743 §36; 1983 c. $800 \S 1 ; 2017$ c.634 §3]

Note: See note under 161.015 (General definitions)
THE EFFECTS OF MENTAL ILLNESS ON CAPITAL SENTENCING

Appendix E

ORS 161.325 Finding of Guilty Except for Insanity

After the defendant is found guilty except for insanity, the court shall, on the basis of the evidence given at the trial or at a separate hearing, if requested by either party, order a

disposition as provided in ORS 161.327 (Commitment or conditional release of person found guilty except for insanity of felony), 161.328 (Commitment of person found guilty except for insanity of misdemeanor) or 161.329 (Order of discharge), whichever is appropriate.

(2)If the court enters an order as provided in ORS 161.327 (Commitment or conditional release of person found guilty except for insanity of felony), it shall also:

(a)Determine on the record the offense of which the person otherwise would have been convicted;

(b)State on the record the qualifying mental disorder on which the defendant relied for the guilty except for insanity defense

(c)State on the record the maximum total period of commitment or conditional discharge under ORS 161.327 (Commitment or conditional release of person found guilty except for insanity of felony) (5); and

(d)Make specific findings on whether there is a victim of the crime for which the defendant has been found guilty except for insanity and, if so, whether the victim wishes to be notified, under ORS 161.326 (Notice to victim), of any hearings and orders concerning the defendant and of any conditional release, discharge or escape of the defendant.

(3)The court shall include in its order the information described in subsection (2) of this section. 
THE EFFECTS OF MENTAL ILLNESS ON CAPITAL SENTENCING

(4)Except under circumstances described in ORS 137.076 (Blood or buccal sample and thumbprint of certain convicted defendants required) (4), whenever a defendant charged with any offense listed in ORS 137.076 (Blood or buccal sample and thumbprint of certain convicted defendants required) (1) has been found guilty of that offense except for insanity, the court shall, in any order entered under ORS 161.327 (Commitment or conditional release of person found guilty except for insanity of felony), 161.328 (Commitment of person found guilty except for insanity of misdemeanor) or 161.329 (Order of discharge), direct the defendant to submit to the obtaining of a blood or buccal sample in the manner provided in ORS 137.076 (Blood or buccal sample and thumbprint of certain convicted defendants required). [1971 c.743 \$44; 1977 c.380 §; 1979 c.885 §1; 1981 c.711 §1; 1983 c.800 §5; 1991 c.669 §8; 1999 c.97 §2; 2005 c.337 §1; 2010 c. 89 §9; 2011 c.708 §40; 2011 c.724 §2; 2017 c.634 §6; 2019 c. 329 §2]
THE EFFECTS OF MENTAL ILLNESS ON CAPITAL SENTENCING

Appendix F

ORS 419C.520 Definitions

As used in ORS 419C.411 (Disposition order), 419C.522 (Qualifying mental disorder as affirmative defense) to 419C.527 (Procedure for state to obtain mental examination of youth) and 419C.529 (Finding of serious mental condition) to 419C.544 (Transfer of cases from juvenile panel to adult panel of Psychiatric Security Review Board):

(1) “Conditional release" includes but is not limited to the monitoring of mental and physical health treatment

(2) “Qualifying mental disorder” does not include an abnormality:

(a)Manifested only by repeated criminal or otherwise antisocial conduct;

(b)Constituting solely a personality disorder; or

(c)Constituting solely a conduct disorder.

(3) "Serious mental condition" means a condition that requires supervision and treatment services for the safety of others and is:

(a)A mental illness of major depression;

(b)A mental illness of bipolar disorder; or

(c)A mental illness of psychotic disorder. [2005 c.843 §3; 2007 c.889 §3; 2017 c. $634 \S 22$ 
Appendix G

ORS 161.095 Requirements for Criminal Liability

(1)The minimal requirement for criminal liability is the performance by a person of conduct which includes a voluntary act or the omission to perform an act which the person is capable of performing.

(2)Except as provided in ORS 161.105 (Culpability requirement inapplicable to certain violations and offenses), a person is not guilty of an offense unless the person acts with a culpable mental state with respect to each material element of the offense that necessarily requires a culpable mental state. [1971 c.743 §8] 